\title{
Owls as bioindicators: their spatial and temporal aspects in Eastern Europe
}

$I_{\text {Biomonitoring }}$

Laboratory, Institute of

Problems in Ecology

and Mineral Wealth

Tatarstan Academy of

Sciences, Daurskaya str.,

28, Kazan 420087, The

Republic of Tatarstan,

Russia

Corresponding author,

E-mail:parus.cyanus@

rambler.ru

\author{
Arthur Askeyev $^{1}$, Oleg Askeyev ${ }^{1 *}$, Igor Askeyev $^{1}$
}

\begin{abstract}
The article presents the unique results of a study of the spatial distribution of owls in the territory of the Republic of Tatarstan by season of the year on long-term data. Ravkin's transect method was used to census fixed randomly selected plots spread over a large geographic area. Abundance a lot of species of owls strong changed of different seasons of the year. In general, owls were indifferent to latitudinal, longitudinal, and altitude gradients in the territory of the Republic of Tatarstan, especially in winter and autumn periods. Probability of occurrences of boreal and pygmy owls can be used as indicators of the biological diversity of forest ecosystems in winter period.
\end{abstract}

\section{KEYWORDS}

owls; spatial distribution; seasons of the year; indicators of biological diversity; density; forest; Republic of Tatarstan

(cc)BB-NC-ND $\odot 2019$ Maria Smati, Mahmoud Kitouni

This is an open access article distributed under the Creative Commons Attribution-NonCommercial-NoDerivs license

\section{INTRODUCTION}

In the twenty-first century, in the era of global climate change, the most impotent problem of humanity is the protection of rare and endangered species, the preservation of the biodiversity of ecosystems and its individual components (Groom et al. 2006; Butchart et al. 2010). The climate in the Republic of Tatarstan has significant changes over the past 30 years (Askeyev O. et al. 2018). These changes can have a significant impact on forest ecosystems both directly, increasing the survival rate of birds in the winter and nesting period (Askeyev O. et al. 2017, 2018), and indirectly, affecting the state of forests and feed base (Askeyev A. et al. 2017).

The group of birds chosen by us belongs to the order Strigiformes, whose representatives are the final ecological link in ecosystems (Korpimäki 1992; Newton 2002). The total number of owls in ecosystems is small and abundance of most species of owls in Europe is declining (Elts et al. 2003; Mammen \& Stubbe 2003, 2005; Hörnfeldt et al. 2005; Saurola 2009; Green et al. 2016). In the Republic of Tatarstan, owls are rare species of birds and all species except bearded great gray owl are listed in the Red Book of the Republic of Tatarstan (The Red Book of the Republic of Tatarstan, 2016). Twelve species of owls live in the territory of the Republic of Tatarstan: Eurasian eagle-owlBubo bubo (Linnaeus, 1758); snowy owl-Nyctea scandiaca (Linnaeus, 1758); long-eared owl-Asio otus (Linnaeus, 1758); short-eared owl-Asio flammeus (Pontoppidan, 1763); boreal owl-Aegolius funereus (Linnaeus, 1758); hawk owl-Surnia ulula (Linnaeus, 1758); pygmy owl-Glaucidium passerinum (Linnaeus, 1758); little owl-Athene noctua (Scopoli, 1769); scops owl-Otus scops (Linnaeus, 1758); tawny owl-Strix aluco (Linnaeus, 1758); Ural owl-Strix uralensis (Pallas, 1771); and great gray owl-Strix nebulosa (Forster, 1772). For the rational protection of these species of birds in the territory of the Republic of Tatarstan, long-term monitoring of their numbers is necessary, taking into account seasonality. In addition, knowledge of the distribution and abundance of birds of prey can be 
important for the bioindication of the biological diversity of forest ecosystems (Chamberlain et al. 2009; Pakkala et al. 2014; Schütz \& Schulze 2018). The aim of our work is to study the spatial distribution of owls in the territory of the Republic of Tatarstan in different seasons of the year.

\section{METHODS}

\subsection{Study area}

Located toward the eastern limit of Europe the Republic of Tatarstan is located between $53.58-56.40^{\circ} \mathrm{N}$ and $47.50-54.00^{\circ} \mathrm{E}$. Historically, this area has been considered to be in the Middle Volga and PreUral regions of European Russia. It covers an area of approximately $68,000 \mathrm{~km}^{2}$ and consists of two major natural zones, i.e., forest and forest steppe. Forest covers about $20 \%$ of this mostly flat landscape (53-382 $\mathrm{m}$ a.s.l). The climate of the region is continental, typical of Eastern Europe. Average annual temperature is $2-5^{\circ} \mathrm{C}$ with January being the coldest month (mean temperature from -12 to $-14^{\circ} \mathrm{C}$ ) and July being the warmest month $\left(19-21^{\circ} \mathrm{C}\right)$.

\subsection{Bird number data}

The study of bird fauna was conducted in the territory of the Republic of Tatarstan for 5 years during the period from November 1, 2013 to October 31, 2018. The seasons were divided into three periods: winter (November 1-March 1), nesting (March 2-June 30), and the period of autumn migrations (July 1-October 31). In addition, the accounts in each season were divided into forest and open landscapes. Fieldwork was carried out in the morning according to Y. S. Ravkin's transect methods (Ravkin 1967) without a fixed strip width with subsequent density conversion using group mean detection ranges. Counts were used to estimate numbers per $\mathrm{km}^{2}$, based on the mean detection distances. In this work, we used the average density of each species for 5 years. Long-term data were used to level the annual fluctuations in the number of birds and the annual differences of ecological and phenological nature (Newton 2002). Every year covering 40 plots in each period with a total area of more than $5.500 \mathrm{~km}^{2}$ was surveyed. For the study of the ecological and geographical preferences of owls in the winter and nesting seasons, the following were noted for each site: altitude above sea level in $\mathrm{m}$ ( $\mathrm{m}$ a.s.l.), latitude, longitude, and the prevalence of conifers in forests on a numerical scale (0-forests in which the proportion of conifers does not exceed $1 \%$; 1 -forests with conifers $1 \%-10 \%$; 2 -forests with a share of conifers $10 \%-25 \%$; 3 -forests where the proportion of conifers is $25 \%-50 \%$; 4 -forest tracts with coniferous shares $50 \%-75 \%$; 5 -the proportion of conifers is more than $75 \%$ ). For each site, the density and occurrence of each species of owls, the total number species and total density of birds, and the Shannon index were estimated.

\subsection{Data analysis}

Individual species responses to environmental factors were modeled with the use of binomial generalized linear models (GLMs) with a logit link. The hypothesis was that the probability of occurrence of a species increased or decreased monotonically with factors. Both linear and quadratic forms of separate environmental factors were considered because species can have a unimodal response to an environmental gradient. The best explanatory model was selected based on the Akaike information criterion (AIC), where the model with the lowest $\mathrm{AIC}$ is the one that best fits the data. To test the relationship of the frequency of occurrence of owls with the total density of birds, the total number of species, and the biodiversity index, a binomial logistic regression model (GLM) was used. Calculation and visualization were done using Past version 3.16.

\section{RESULTS}

During the observation period in the territory of Tatarstan, we observed all 12 species of owls. Ten species were noted in forests and four species in open landscapes. The number of each individual species as a whole was small and did not exceed 0.76 individuals per square kilometer.

\subsection{Winter period}

In total, in winter, we observed eight species of owls: six in forest and two in open landscapes (Table 1). The most abundant species of owls in forest area were: Ural owl, pygmy owl, and boreal owl (Table 1). The abundance of other species did not exceed 0.1 individuals per square kilometer (Table 1 ).

In open landscapes during the winter period, only two species of owls were noted, whose density was very low and did not exceed 0.05 individuals per square kilometer (Table 1).

For order Strigiformes in the winter period, it is worth noting the uniform distribution in the forests of the Republic of Tatarstan and indifference to selected environmental factors. Only shares of conifers were the one variable that significantly explained about the distribution of owls in our study area. Binomial regression showed that only one species (boreal owl) had statistically significant relationships with shares of conifers (Table 2). All the other best models were linear according to the AIC criterion. However, only one model (as previously mentioned) was significant.

We found that the probability of detecting certain species of owls had a significant relationship with the species richness of birds. The greater the total number of species of birds in the forest sites, the higher the probability of occurrences of boreal owl and pygmy owl (Fig. 1).

In addition, we found a significant correlation between the probability of occurrences of the boreal owl and the pygmy owl and the value of the Shannon index. The probability of occurrences of these owls was close to zero in forest sites with value of the Shannon index less than two (Fig. 2). 
Table 1. Mean density (SD) (individuals per km2) of owls in winter in the territory of the Republic of Tatarstan

\begin{tabular}{c|c|c}
\hline \multirow{2}{*}{ Species } & \multicolumn{2}{|c}{ Mean density (SD) } \\
\cline { 2 - 3 } & Forest & Open landscapes \\
\hline Ural owl & $0.56(0.14)$ & - \\
\hline Pygmy owl & $0.35(0.22)$ & - \\
\hline Boreal owl & $0.23(0.16)$ & - \\
\hline Hawk owl & $0.1(0.02)$ & - \\
\hline Long-eared owl & $0.001(0.002)$ & $0.05(0.03)$ \\
\hline Eurasian eagle-owl & $0.001(0.002)$ & $0.02(0.01)$ \\
\hline Snowy owl & - & - \\
\hline Short-eared owl & & - \\
\hline
\end{tabular}

Table 2. Binominal logistic regression models based on the presence-absence data of environmental factors in forests of Tatarstan during the winter period (the slope coefficient $A \pm S E$ regression equation and significant $P$ values are in bold)

\begin{tabular}{|c|c|c|c|}
\hline Species & Coefficient & SE & $P$ \\
\hline \multicolumn{4}{|c|}{ Altitude } \\
\hline Boreal owl & -0.01 & 0.009 & 0.27 \\
\hline Pygmy owl & -0.002 & 0.007 & 0.72 \\
\hline Ural owl & 0.002 & 0.006 & 0.72 \\
\hline \multicolumn{4}{|c|}{ Latitude } \\
\hline Boreal owl & 0.07 & 0.98 & 0.94 \\
\hline Pygmy owl & 0.066 & 0.83 & 0.93 \\
\hline Ural owl & 0.39 & 0.71 & 0.58 \\
\hline \multicolumn{4}{|c|}{ Longitude } \\
\hline Boreal owl & -0.29 & 0.34 & 0.37 \\
\hline Pygmy owl & -0.30 & 0.28 & 0.27 \\
\hline Ural owl & 0.18 & 0.21 & 0.40 \\
\hline \multicolumn{4}{|c|}{ Share of conifers } \\
\hline Boreal owl & 0.07 & 0.34 & 0.009 \\
\hline Pygmy owl & -0.003 & 0.18 & 0.98 \\
\hline Ural owl & 0.12 & 0.15 & 0.43 \\
\hline
\end{tabular}

For pygmy owl, we observed an increase in the probability of occurrences with a high total density of birds in sites (Fig. 3). The higher the total density of birds, the greater the probability of occurrences of pygmy owl.

\subsection{Nesting period}

In the nesting period in the territory of the Republic of Tatarstan, 11 species of owls were recorded: nine in forest and three in open landscape (Table 3). The most abundant species of owls in the forests of Tatarstan in this period was the longeared owl, with a density of 0.51 individuals per square kilometer (Table 3). It lives from the dark coniferous forests in the north of study area to the deciduous forests in the south of the Tatarstan. The Ural owl was second in abundance in the forests of the Republic of Tatarstan in the nesting period (Fig. 4), with a density of 0.41 individuals per square kilometer (Table 3). As 
Boreal Owl

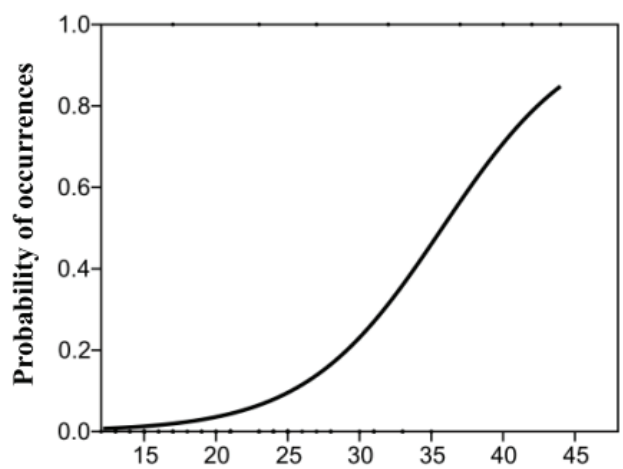

\section{Pygmy Owl}

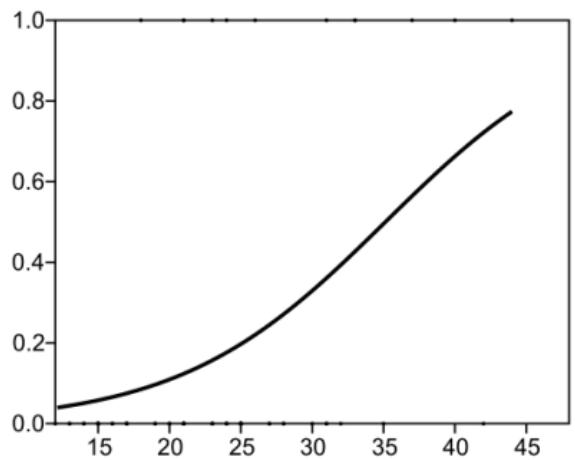

Total bird species

Figure 1. Relation between the probability of occurrences of boreal owl and pygmy owl and bird species communities

Boreal Owl

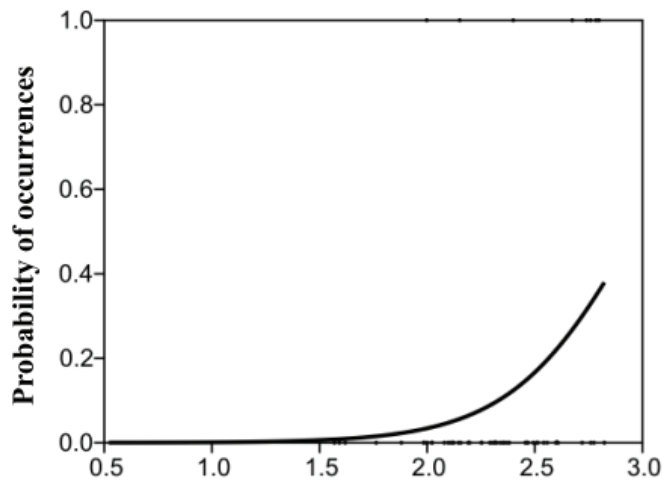

Pigmy Owl

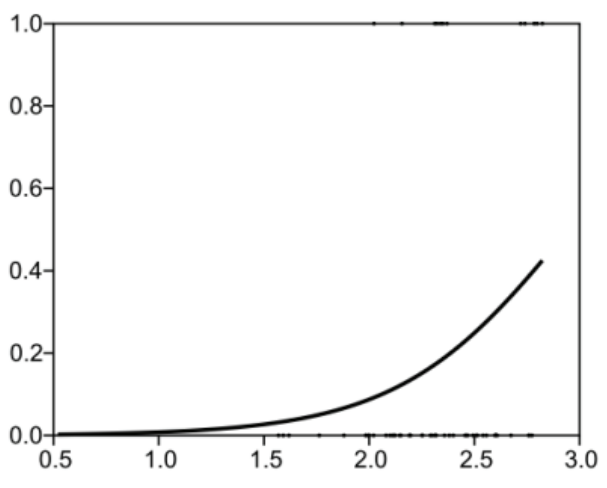

Shannon index

Figure 2. Relation between the probability of occurrences of boreal owl and pygmy owl and the Shannon index of bird communities

Pigmy Owl

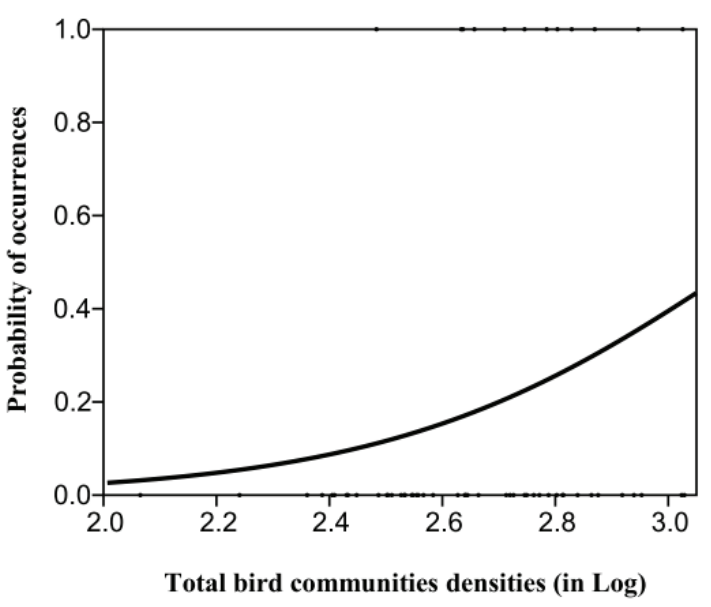

Figure 3. Relation between the probability of occurrences of pygmy owl and densities of total bird communities the previous species, Ural owl lives in forests of any type of the Republic of Tatarstan. The shares of conifers were the variable that explained most about the distribution of owls in the nesting period in our study area. Binomial regression showed that species (boreal owl, pygmy owl, and tawny owl) had statistically significant relationships with shares of conifers (Table 4). Only boreal owl had statistically significant relationships with latitude (Table 4). All the other best models were linear according to the AIC criterion. However, only four models (Table 4) were significant. Basically, this relationship explains that pygmy owl in the territory of the Republic of Tatarstan prefers mixed forests with a predominance of coniferous trees (Table 4). Boreal owl (Fig. 5) prefers forests with a high proportion of coniferous species in the north of the Republic of Tatarstan (Table 4). Tawny owl in the nesting period in the forests of the Republic of Tatarstan lives mainly in old deciduous forests (Table 4).

The abundance of the remaining owls was very low and did not exceed 0.01 individuals per square kilometer (Table 3). 
Table 3. Mean density (SD) (individuals per km2) of owls during the nesting period in the territory of the Republic of Tatarstan

\begin{tabular}{c|c|c}
\hline \multirow{2}{*}{ Species } & \multicolumn{2}{|c}{ Mean density (SD) } \\
\cline { 2 - 3 } & Forest & Open landscapes \\
\hline Long-eared Owl & $0.51(0.13)$ & $0.1(0.02)$ \\
\hline Ural owl & $0.41(0.07)$ & - \\
\hline Pygmy owl & $0.22(0.12)$ & - \\
\hline Tawny owl & $0.15(0.04)$ & - \\
\hline Boreal owl & $0.11(0.06)$ & - \\
\hline Great gray owl & $0.01(0.01)$ & - \\
\hline Eurasian eagle-owl & $0.003(0.002)$ & - \\
\hline Scops owl & $0.001(0.002)$ & $0.76(0.57)$ \\
\hline Hawk owl & $0.001(0.002)$ & - \\
\hline Short-eared owl & - & $-17)$ \\
\hline Little owl & - & - \\
\hline
\end{tabular}

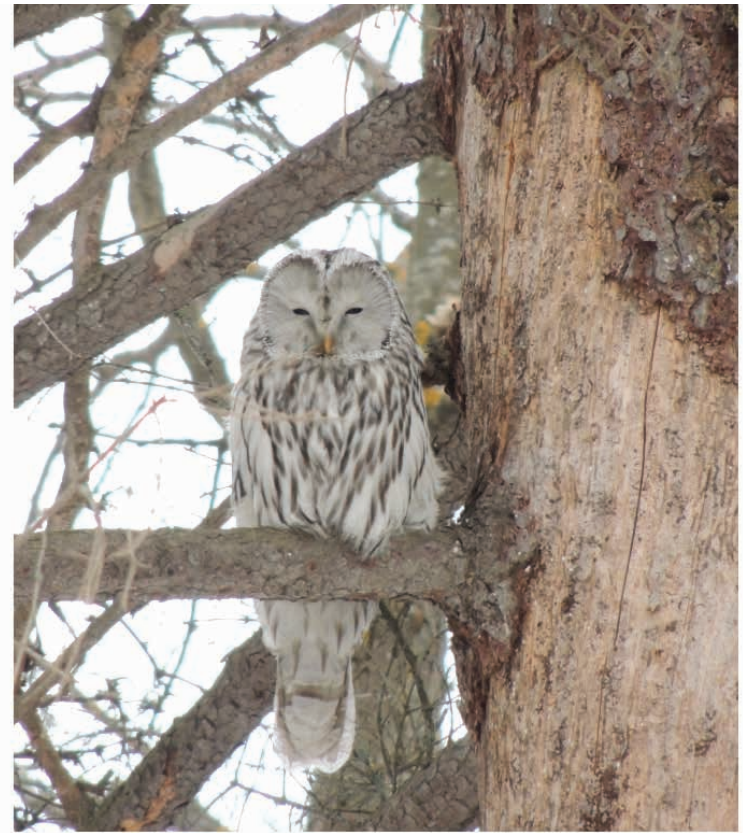

Figure 4. Ural owl, one of the most common forest owl species in the Republic of Tatarstan

Table 4. Binominal logistic regression models based on the presence-absence data of environmental factors in forests of the Republic of Tatarstan in the nesting period (only the slope $A \pm S E$ regression equation is shown with reliable values of $P<0.05$ in bold) NS, nonsignificant relation

\begin{tabular}{c|c|c|c|c}
\hline Species & Altitude & Latitude & Longitude & Share of conifers \\
\hline Boreal owl & NS & $0.3 \pm 0.12$ & NS & $0.07 \pm 0.03$ \\
\hline Pygmy owl & NS & NS & NS & $0.09 \pm 0.04$ \\
\hline Ural owl & NS & NS & NS & $-0.06 \pm 0.03$ \\
\hline Tawny owl & NS & NS & NS & NS \\
\hline Long-eared owl & NS & NS & NS \\
\hline
\end{tabular}

In open landscapes in the territory of the Republic of Tatarstan, three species of owls were noted (Table 3). The most abundant owl species was the short-eared owl (Fig. 6), with a density of 0.76 individuals per square kilometer. The density of the little owl and the long-eared owl in the nesting period was 0.31 and 0.1 individuals per square kilometer, respectively (Table 3). All these species were evenly distributed throughout the territory of the Republic of Tatarstan.

\subsection{Period of autumn migrations}

During the autumn migrations in the territory of the Republic of Tatarstan, 10 species of owls were observed: nine in forest ecosystems and three in open landscapes (Table 5).

The most abundant owl species in the forests of the Republic of Tatarstan in the period of autumn migrations was the Ural owl, with a density of 0.58 individuals per square kilometer. The pygmy owl, boreal owl, and long-eared owl were also very abundant, and their density was $0.36,0.28$, and 0.24 individuals per square kiolmeter, respectively.
Table 5. Mean density (SD) (individuals per $\mathrm{km} 2$ ) of owls during the autumn migrations in the territory of the Republic of Tatarstan

\begin{tabular}{c|c|c}
\hline \multirow{2}{*}{ Species } & \multicolumn{2}{|c}{ Mean density (SD) } \\
\cline { 2 - 3 } & Forest & Open landscapes \\
\hline Ural owl & $0.58(0.09)$ & - \\
\hline Pygmy owl & $0.36(0.33)$ & - \\
\hline Boreal owl & $0.28(0.24)$ & - \\
\hline Long-eared owl & $0.24(0.05)$ & - \\
\hline Tawny owl & $0.05(0.03)$ & $0.5(0.18)$ \\
\hline Hawk owl & $0.05(0.015)$ & - \\
\hline Little owl & $0.03(0.02)$ & - \\
\hline Eurasian eagle-owl & $0.02(0.02)$ & $0.17(0.16)$ \\
\hline Great gray owl & $0.01(0.01)$ & - \\
\hline Short-eared owl & & -
\end{tabular}




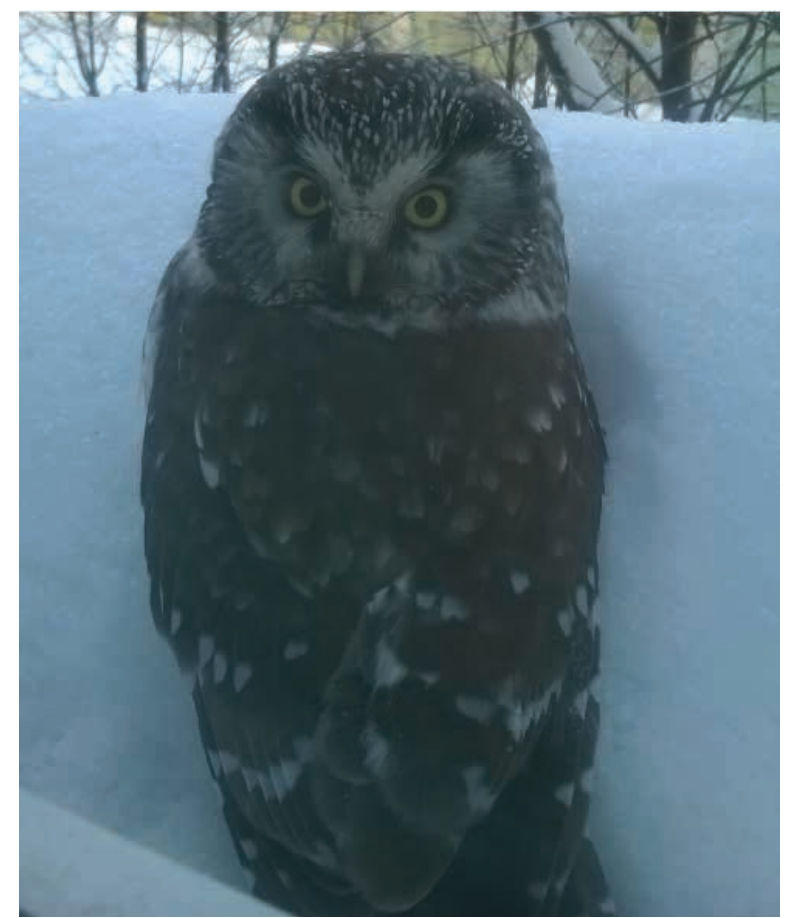

Figure 5. Boreal owl, one of the most common owl species in coniferous forests in winter in the Republic of Tatarstan

In open ecosystems, the little owl was the most abundant species in the period (Table 5). Its number during this period was the highest among all seasons of the year, which was 0.5 individuals per square kilometer (Table 5). The abundance of short-eared owl and long-eared owl compared with the nesting period was much less (Tables 3 and 5).

For all species of owls in forest and open landscapes during the autumn migration period, there was a uniform distribution over the territory of the Republic of Tatarstan.

\section{DISCUSSION}

Density and species assemblages of owls significantly differ by seasons of year (del Hoyo at al. 1999). The greatest number of owl species is observed in the nesting period, but largest density for most owl species is observed during the period of autumn migrations (Mikkola 1983, Newton 1998, 2008). Therefore, the work on the conservation of owls must be carried out taking into account their seasonal abundance. Compared to previous studies in the Republic of Tatarstan (Askeyev I. \& Askeyev O. 1999), the number of nesting sites and density of boreal owl and pygmy owl have increased, while the abundance of tawny owl continues to decrease. In our opinion, the increase in the abundance of boreal owl and pygmy owl is associated with an increase in the number of many small passerine birds (Askeyev O. et al. 2018) in the territory of Tatarstan. Opposite in a lot of country in Europe f.e. Sweden (Hörnfeldt et al. 2005), Finland (Saurola 2009), Estonia (Elts et al. 2003), Germany (Mammen \& Stubbe 2003, 2005) is a decrease in the number Boreal Owl in result, reduction of suitable trees for

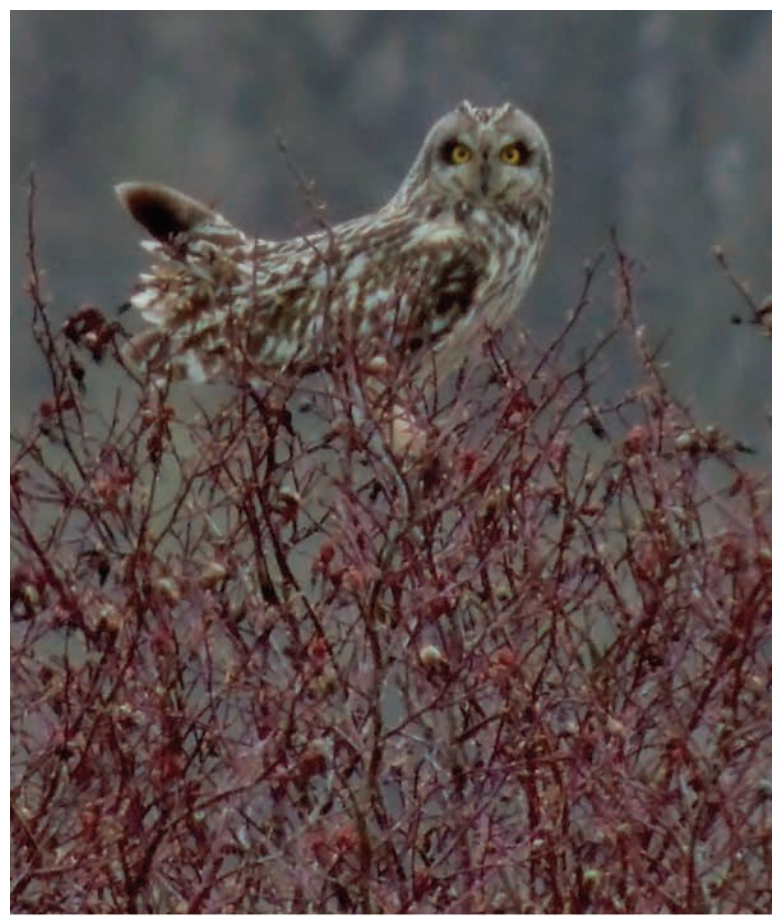

Figure 6. Short-eared owl, one of the most common owl species in open landscapes in the Republic of Tatarstan

breeding. Density decrease for tawny owl can partly be attributed to the decrease in the amount of old forest and competitive relations with Ural owl in the territory of the Republic of Tatarstan. Unlike Finland (Saurola 2009), Sweden (Green et al. 2016), and Germany (Mammen \& Stubbe 2003, 2005), where there is a reliable trend to increase the number of long-eared owls, in the Republic of Tatarstan the abundance of this species has remained at the same level for 20 years. In Slovenia (Vrezec 2003) and Finland (Solonen 1996, Pietiainen \& Saurola 1997), in the nesting period, the density of boreal owl and tawny owl is higher than that in our study. The abundance of Ural owl in Finland (Solonen 1996, Pietiainen \& Saurola 1997) and Belarus (Tischechkin \& Ivanovsky 2000) is less than that in our study in the nesting period (Saurola 2002, Saurola \& Francis 2004, Zurawlew 2018). These differences in the density and dynamics of the abundance of owls on different parts of the European continent may indicate that there are differences in the state of ecosystems in different parts of Europe, which of course is due to differences in human influence. Therefore, measures for numbers and protection of owls should be carried out over a large area (Cieślak M. \& Kwieciński Z. 2009, Kwieciński Z. 2017).

The increase in the probability of occurrences for the pygmy owl and the boreal owl in forest sites with a large number of bird species and a high value of the Shannon index gives us the opportunity to talk about these species of birds as universal bioindicators of the biological diversity of forest ecosystems in winter (Mikkola 1983, Newton 1998). In Finland (Pakkala et al. 2014), bioindicative abilities were found for the pygmy owl in forest ecosystems. In the Italian Alps high biodiversity values were recorded at the breeding sites of boreal and 
pygmy owls (Sergio et al. 2006). In addition, have suggestions (Korpimäki \& Hakkarainen 2012) that the boreal owl, in breeding period, could be a better indicator species of biodiversity value than many other birds of prey (Korpimäki 1986).

In general, owls were indifferent to latitudinal, longitudinal, and altitude gradients in the territory of the Republic of Tatarstan. In studies conducted over a wide area during the winter period in Siberia (Vartapetov et al. 2005), indifference of Ural owl to environmental factors is also noted. In Slovenia, in the nesting period, different species of owls are distributed unevenly in the altitude gradient (Vrezec 2003). In our study, is shown the complete indedentiality of all species of owls to this gradient in any period of the year. The most sensitive species to environmental conditions was the boreal owl. This species pre- fers coniferous forests during the nesting and winter periods in the territory of the Republic of Tatarstan. Prefere of conifer forest of Boreal Owl noted in Finland (Korpimäki \& Hakkarainen 2012).

Our research has been a monitoring method, producing unique data on the recent trends and spatial distribution in all seasons of year of all species of owls in Eastern Europe. We consider and urge the scientific community to become more active cooperation over larger areas across national boundaries in Europe is urgently needed for reliable monitoring of owls not only in the breeding seasons but at other seasons of the year (Hagemeijer \& Blair 1997, Cieślak \& Kwieciński 2009, Cieślak 2017).

\section{References}

Askeyev, A., Askeyev, O. \& Askeyev, I. (2017) Long-term woodpecker winter population dynamics in the Tatarstan Republic. Vogelwelt, 137, 130-133.

Askeyev, I. \& Askeyev, O. (1999) The avifauna of the Republic of Tatarstan (abstract of the current state). Kazan, 124 p. (in Russian)

Askeyev, O., Askeyev, A. \& Askeyev, I. (2017) Bird winter population dynamics at the eastern edge of Europe. Vogelwelt, 137, 134-142.

Askeyev, O., Askeyev, A. \& Askeyev, I. (2018) Recent climate change has increased forest winter birds densities in East Europe. Ecological research, 33(2), 445-456.

Butchart, S., Walpole, M., Collen, B., Van Strien, A., Scharlemann, J.P., Almond R.E. et al. (2010) Global biodiversity: indicators of recent declines. Science, 328(5982), 1164-1168.

Chamberlain, D., Glue, D., \& Toms, M. P. (2009) Sparrowhawk Accipiter nisus presence and winter bird abundance. Journal of Ornithology, 150(1), 247-254.

Cieślak, M. \& Kwieciński Z. (2009) Moult and breeding of captive Northern Hawk Owls Surnia ulula. In: Johnson D.H., Van Nieuwenhuyse D. \& Duncan J.R. (eds) Proc. Fourth World Owl Conf. OctNov 2007, Groningen, The Netherlands. Ardea 97(4): 571-579.

Cieślak, M. (2017) Feathers of European owls. Insights into species ecology and identification. Editorial team into English version: Sterno A., Kwieciński Z., Grudzińska -Sterno M. Oriolus Publishing House. Uppsala, Sweden.

del Hoyo, J., Elliott, A. \& Sargatal, J. eds. (1999) Handbook of the Birds of the Word. Vol. 5. Barn-owls to Hummingbirds. Lynx Edicions, Barcelona.

Elts, J., Kuresoo, A., Leibak, E., Leito, A., Lilleleht, V., et al. (2003) Status and numbers of Estonian birds, 1998-2002. Hirundo, 16, 58-83. (In Estonian)

Green, M., Haas, F., \& Lindström, Å. (2016) Övervakning av fåglarnas populationsutveckling: årsrapport för 2015. Biologiska institutionen, Lunds universitet.

Groom, M., Meffe, G., \& Carroll, C. (2006) Principles of conservation biology. Sunderland: Sinauer Associates.
Hagemeijer, W. J., \& Blair, M. J. (1997). The EBCC Atlas of European Breeding Birds: Their Distribution and Abundance. T \& AD Poyser, London.

Hörnfeldt, B., Hipkiss, T. \& Eklund, U. (2005) Fading out of vole and predator cycles? Proc. R. Soc. Lond., 272, 2045-2049.

Korpimäki, E. (1986) Niche relationships and life-history tactics of the three sympatric Strix owl species in Finland. Ornis Scandinavica 17(2): 126-132. DOI: 10.2307/3676861

Korpimäki, E. (1992) Population dynamics of Fennoscandian owls in relation to wintering conditions and between-year fluctuations of food. The ecology and conservation of European owls, 1-10.

Korpimäki, E. \& Hakkarainen, H. (2012) The Boreal owl ecology, behaviour and conservation of a forest-dwelling predator. Cambridge university press, $259 \mathrm{p}$.

Kwieciński, Z. (2017) Difficulties in finding feathers of the Eurasian Pygmy Owl G. passerinum during fieldwork. In: Cieślak M. Feathers of European owls. Insights into species ecology and identification. Editorial team into English version: Sterno A., Kwieciński Z., Grudzińska -Sterno M. Oriolus Publishing House. Uppsala, Sweden. Pp: 195.

Mammen, U. \& Stubbe, M. (2003) Monitoring of raptors and owls in Europe: Annual report for 2002. Förderverein für Ökologieund Monitoring von Greifvogel und Eulenarten, Halle/Saale.

Mammen, U. \& Stubbe, M. (2005) The situation of raptors and owls in Germany, 1999-2002. Vogelwelt, 126, 53-65. (In German)

Mikkola, H. (1983) Owls of Europe. T \& A.D Poyser Ltd. 19: 178-212.

Newton, I. (1998) Population limitation in birds. Academic Press, London.

Newton, I. (2002) Population limitation in Holarctic owls. Ecology and conservation of owls, 3-29.

Newton, I. (2008) The Migration Ecology of Birds. Academic Press.

Pakkala, T., Lindén, A., Tiainen, J., Tomppo, E. \& Kouki, J. (2014) Indicators of forest biodiversity: which bird species predict high breeding bird assemblage diversity in boreal forests at multiple spatial scales? Finnish Zoological and Botanical Publishing Board. In Annales Zoologici Fennici (pp. 457-476). 
Pietiainen \& Saurola (1997) Ural Owl Strix uralensis. Pages 412-413 in W.J.M. Hagemeijer and MJ. Blair (eds.), The EBCC atlas of European breeding birds. T. \& A.D. Poyser, London, U.K.

Ravkin, YS (1967) On the procedure of bird census in forest landscapes. In: Priroda ochagov kleshchevogo entsefalita na Altae, pp 66-75 (in Russian).

Red Book of Republic of Tatarstan (2016) Kazan: Publisher «Idel-Press», $760 \mathrm{p}$ (in Russian).

Saurola, P. (2002) Natal dispersal distances of Finnish Owl: results from ringing. In: Newton I., Kavanagh R., Olsen J., Taylor I. (eds.). Ecology and Conservation of Owl. CSIRO Publishing, Melbourne, Australia.

Saurola, P. \& Francis (2004) Estimating population parameters and dispersal distances of owl from nationally coordinated ringing data in Finland. Animal Biodiversity and Conservation, 27, 1: 403-415.

Saurola, P. (2009) Bad news and good news: population changes of Finnish owls during 1982-2007. Ardea, 97(4), 469-483.

Sergio, F., Newton, I., Marchesi, L., \& Pedrini, P. (2006) Ecologically justified charisma: preservation of top predators delivers bio- diversity conservation. Journal Applied Ecology, 43(6), 1049 1055.

Schütz, C. \& Schulze, C. H. (2018) Park size and prey density limit occurrence of Eurasian Sparrowhawks in urban parks during winter. Avian Research, 9(1), 30.

Solonen, T. (1996) Patterns and variations in the structure of forest bird communities in southern Finland. Ornis Fennica, 73(1), 12-26.

Tishechkin, A. V., \& Ivanovsky, V. V. (2000) Die Brutleistung des Uralkauzes im nördlichen Weißrußland. Ornithologische Mitteilungen, 52(3), 76-88.

Vartapetov, L., Livanov, S., Tsibulin, S. \& Evsukova, A. (2005) Winter distribution of birds in the West Siberian Plain. Izvestia of Russian Academy of Sciences, 2, 201-207 (in Russian).

Vrezec, A. L. (2003) Ural, Tawny and Boreal Owls in north Dinaric Alps (central Slovenia). Journal Raptor research, 37(1), 55-62.

Żurawlew P., Kwieciński Z., Grus M., Jelonek K., Kostuj P. (2018) New stands of ural owl Strix uralensis in Wielkopolska. Przegląd Przyrodniczy XXIX, 3 (2018), 107-112. 